\title{
UJI FILTRASI MODEL POLUTAN METHYLEN BLUE MENGGUNAKAN MEMBRAN KULIT TELUR
}

\author{
FITRILAWATI * ${ }^{*}$ YASMIN FAUZIAH, GITA MAULIDA, NORMAN SYAKIR \\ Departemen Fisika, FMIPA, Universitas Padjadjaran \\ Jl. Raya Bandung-Sumedang Km.21 Jatinangor 45363, Sumedang, Jawa Barat
}

*email : fitrilawati@phys.unpad.ac.id

\begin{abstract}
Abstrak. Membran filtrasi merupakan salah satu metode yang banyak digunakan untuk pengolahan air limbah dengan prinsip pemisahan dan pemurnian air. Pada makalah ini dilaporkan hasil uji filtrasi model polutan Methylene Blue (MB) menggunakan membran sel telur (ES, Eggshell) yang diperoleh dari cangkang telur yang direndam dalam larutan asam asetat. Pada uji filtrasi, $5 \mathrm{mg} / \mathrm{L}$ larutan $\mathrm{MB}$ dilewatkan membran dengan bantuan tekanan sebesar 3,4 atm. Hasil uji berupa volume permeat yang mengalir melalui membran dan penurunan konsentrasi permeat dibandingkan dengan konsentrasi MB awal. Konsentrasi permeat hasil filtrasi ditentukan menggunakan spektrofotometer UV-Vis melalui pengukuran penurunan absorbansi. Hasil pengujian menunjukkan molekul MB dapat dipisahkan dari air dengan menggunakan tiga lembar membran ES dengan nilai permeabilitas $3,64 \times 10^{-5}$ darcy dan nilai koefisien rejeksi rata-rata sebesar $30,6 \%$.
\end{abstract}

Kata kunci: membran sel telur (ES), methylene blue (MB), filtrasi, fermeabilitas, koefisien rejeksi

\begin{abstract}
Membrane filtration is a method that is widely used for wastewater treatment with a principle of water separation and purification. In this paper, we report the results of the filtration experiment of pollutant model of Methylene Blue (MB) using eggshell membranes (ES) obtained from eggshells soaked in acetic acid solution. In the filtration experiment, $5 \mathrm{mg} / \mathrm{L}$ of MB solution was flowed through the ES membrane with the help of a pressure of $3.4 \mathrm{~atm}$. The results of the filtration experiment are shown in form of permeate volume that flow through the ES membrane and a decreasing of permeate concentration. The concentration of permeate was determined using a UV-Vis spectrophotometer by observed a decreasing of its absorbance. We found that $\mathrm{MB}$ molecules can be separated from water by using three sheets of ES membrane with a permeability value of $3.64 \times 10^{-5}$ darcy and an average rejection coefficient of $30.6 \%$.
\end{abstract}

Keywords: eggshell membrane (ES), methylene blue (MB), filtration, Permeability, rejection cofficient

\section{Pendahuluan}

Kelangkaan air bersih yang disebabkan oleh pencemaran limbah pewarna sintetis menyebabkan kebutuhan teknologi penjernihan air yang efisien, hemat biaya dan ramah lingkungan. Teknologi penjernihan air sangat diperlukan untuk menjamin tersedianya pasokan air bersih. Ada banyak usaha yang dilakukan untuk pemurnian air tercemar limbah pewarna seperti menggunakan metode degradasi fotokatalitik [1], adsorpsi [2], membran filtrasi [3].

Ada banyak material yang sudah disintesis seperti bahan oksida logam, bahan berbasis karbon, dan bahan berbasis polimer, berturut-turut sebagai bahan fotokatalitik, adsorben, dan membran. Membran sel telur (eggshell, ES) adalah 
salah satu bahan alam (biomaterial) yang banyak dikaji sebagai bahan adsorben polutan warna $[4,5,6]$.

Membran ES, yang merupakan salah satu lapisan dari kulit telur yang berada di antara albumen dan permukaan dalam kulit telur, tersusun dari serat protein sehingga membentuk membran semipermeable yang tidak larut dalam air dengan luas permukaan yang besar. Membran kulit telur memiliki beberapa keunggulan diantaranya murah, mudah diperoleh, ramah lingkungan, tidak beracun dan mudah dimodifikasi melalui berbagai proses sintesis untuk melengkapi kelemahan sifat kimianya. Keunggulan tersebut membuat membran ES banyak diaplikasikan dalam berbagai bidang teknik seperti material, listrik, biomedis dan lingkungan [5].

Membran ES juga memiliki beragam gugus fungsi seperti hidroksil, tiol, karboksil, amino dan amida [7]. Adanya beragam gugus fungsi tersebut membuat membran ES berpotensi digunakan sebagai adsorben, terutama untuk penghapusan berbagai bahan kimia organik dan anorganik dalam air limbah $[6,7]$. Pada banyak publikasi yang telah dilaporkan, membran ES yang digunakan sebagai adsorben polutan warna umumnya dikeringkan dan digerus terlebih dahulu sebelum dicampurkan dengan polutan warna $[7,8,9]$.

Metoda adsorpsi menggunakan membran ES sudah cukup baik dalam menurunkan polutan warna, namun metode adsorpsi dianggap masih kurang efisien karena metoda tersebut bersifat statik. Pada metode adsorpsi, setelah proses adsorpsi masih dibutuhkan tahapan lanjutan yaitu penyaringan untuk memisahkan material pengadsorp dari permeat hasil adsorpsinya.

Filtrasi membran merupakan salah satu metode pengolahan air limbah yang bersifat dinamis, yang dengan satu langkah, langsung menghasilkan permeat (produk hasil saringan). Filter membran juga dapat mencegah pembentukan dan penyebaran bakteri dan virus, serta menghilangkan partikel, kekeruhan, dan sedimen dari air. Prinsip kerja membran adalah dengan menahan partikel yang memiliki ukuran lebih besar dari ukuran pori membran dan meloloskan partikel yang memiliki ukuran lebih kecil dari pori membran. Filtrasi membran memiliki beberapa keunggulan dibandingkan dengan metode lainnya karena prosesnya tidak memerlukan bahan kimia tambahan, konsumsi energi rendah, proses dapat dijalankan pada suhu rendah, mudah ditingkatkan kapasitasnya, tidak membutuhkan kondisi ekstrim dan fleksibel.

Berbeda dengan yang biasa dilakukan dan yang sudah dilaporkan sebelumnya, dalam penelitian ini membran ES tidak digerus halus melainkan dimanfaatkan dalam bentuk lembaran untuk digunakan sebagai filter guna menyaring polutan methylene blue (MB). Adanya gugus hidrofilik pada membran ES yang dapat mengadsorp polutan, diharapkan proses adsorpsi berlangsung bersamaan dengan proses filtrasi

\section{Metode Penelitian}

Bahan yang digunakan pada penelitian ini adalah cangkang telur ayam negeri yang diambil bagian membrannya, asam asetat glasial $\left(\mathrm{CH}_{3} \mathrm{COOH}\right)$ untuk melarutkan cangkang telur, ethanol sebagai media penyimpanan membran telur supaya terhindar dari mikroorganisme, bubuk MB sebagai sebagai model polutan untuk uji filtrasi, dan aquades sebagai pelarut. 
Membran ES dipisahkan dari cangkang kulit telur melalui perendaman menggunakan pelarut asam asetat dengan konsentrasi 15\% selama 30 menit. Pada proses tersebut, kalsium karbonat $\left(\mathrm{CaCO}_{3}\right)$ yang terdapat pada cangkang telur akan terlarut, sehingga membran yang terdapat pada bagian dalam kulit telur dapat dipisahkan dengan mudah. Lapisan membran tersebut diambil menggunakan pinset, kemudian dibilas dengan aquades untuk menghilangkan sisa asam asetat pada membran. Membran tersebut selanjutnya disimpan di dalam wadah tertutup berisi ethanol dan diletakkan dalam lemari penyimpanan dengan temperatur $25^{\circ} \mathrm{C}(\mathrm{T})$ agar terhindar dari serangan mikroorganisme.

Eksperimen filtrasi dilakukan dengan menggunakan setup peralatan filtrasi seperti yang diperlihatkan pada Gambar 1. Peralatan filtrasi tersebut terdiri dari tabung reservoar yang berfungsi sebagai wadah larutan MB, katub 1 berfungsi untuk mengalirkan gas dari tabung nitrogen guna mengontrol tekanan pada proses filtrasi, statif sebagai penopang rumah membran, katub 2 berfungsi untuk mengalirkan gas dari tabung nitrogen menuju tabung reservoar, katub 3 berfungsi untuk mengalirkan larutan MB dari tabung reservoar menuju rumah membran, rumah membran sebagai tempat memasang membran pada proses filtrasi, gelas ukur sebagai tempat menampung permeat hasil filtrasi.

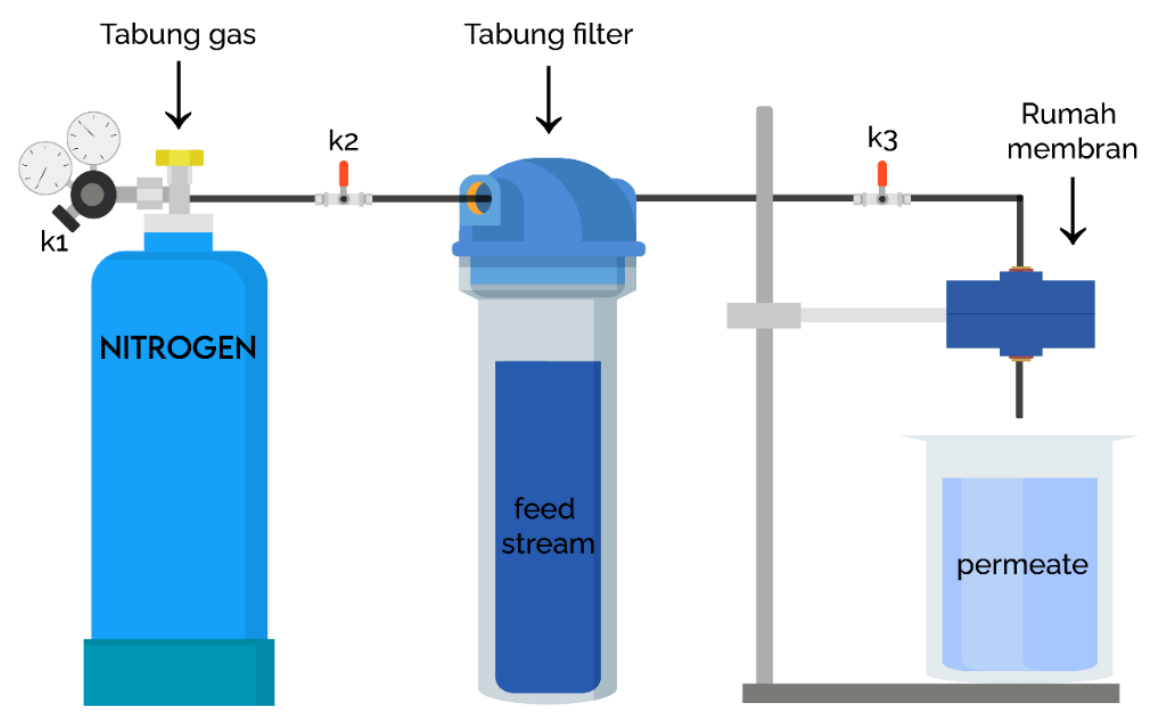

Gambar 1. Diagram peralatan uji filtrasi dengan menggunakan membran ES

Uji filtrasi larutan MB oleh membran ES diawali dengan memasukkan $1000 \mathrm{~mL}$ larutan MB konsentrasi $5 \mathrm{mg} / \mathrm{L}$ ke dalam tabung reservoar. Kemudian membran ES dipasangkan pada rumah membran (membran holder). Saat pemasangan membran ES perlu dipastikan bahwa posisi membran tersebut sudah tepat sehingga tidak terjadi kebocoran. Setelah itu tekanan tabung nitrogen diatur sebesar 3,4 atm dan buka katub pertama. Kemudian katub kedua dibuka, sehingga tekanan masuk ke dalam tabung reservoar yang akan mendorong larutan menuju rumah membran sehingga terjadi proses filtrasi larutan MB oleh membran ES. Setelah itu, katub ketiga dibuka sehingga larutan $\mathrm{MB}$ hasil penyaringan (permeat) keluar dan ditampung di dalam gelas ukur. Volume permeat ( $V_{\text {Permeat }}$ ) diukur untuk setiap waktu penyaringan. Larutan MB dan permeat yang dihasilkan pada berbagai selang waktu dikarakterisasi menggunakan spektrofotometer UV-Vis pada rentang 
panjang gelombang $500 \mathrm{~nm}$ sampai dengan $750 \mathrm{~nm}$. Konsentrasi MB yang tersisa pada permeat ditentukan dengan menggunakan kurva kalibrasi.

\section{Hasil dan Pembahasan}

Membran ES yang didapatkan dari cangkang telur ayam diperlihatkan pada Gambar 2. Pemisahan membran dari cangkang telur menggunakan asam asetat akan lebih mudah melalui perendaman dibandingkan tanpa perendaman. Hal ini dikarenakan asam asetat dikategorikan sebagai zat asam lemah yang memiliki kemampuan untuk merusak beberapa zat seperti kalsium yang merupakan komponen utama penyusun cangkang telur. Saat cangkang telur direndam dalam larutan asam asetat, kalsium karbonat akan bereaksi dengan asam asetat membentuk garam kalsium karbonat, sehingga kalsium pada cangkang telur akan melunak dan terlepas dari membran.

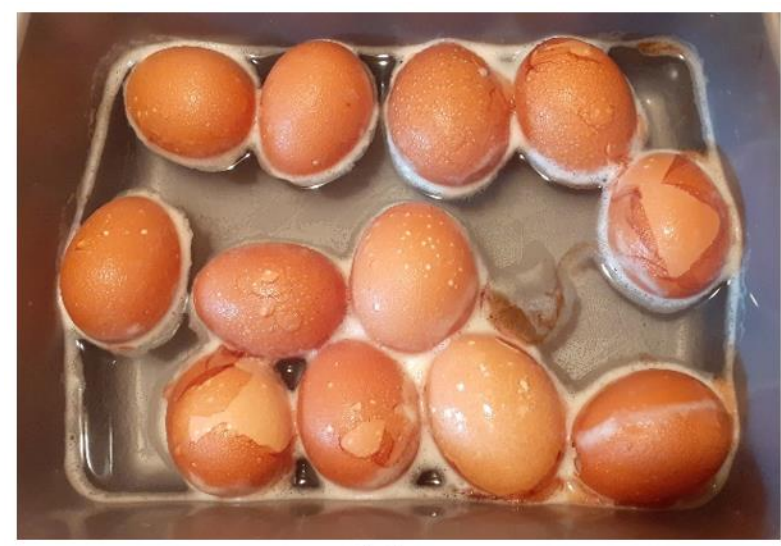

(a)

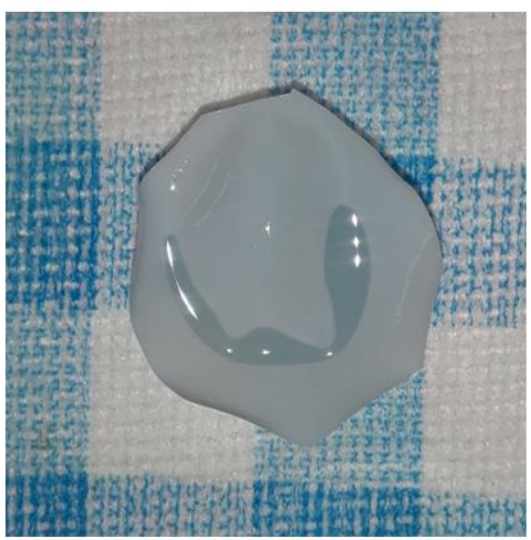

(b)

Gambar 2. Proses perendaman cangkang telur dalam larutan asam asetat $15 \%$ (a) dan membran ES yang dihasilkan setelah proses perendaman dalam asam asetat (b)

Hasil filtrasi berupa permeat yang keluar dari membran dan ditampung yang volumenya diukur sebagai fungsi waktu. Hasil ini mengindikasikan tiga lembar membran ES yang dibuat dapat digunakan sebagai membran fitrasi. Permeat hasil filtrasi menggunakan membran ES menunjukkan adanya sedikit perubahan warna dibandingkan larutan MB sebelum mengalami filtrasi seperti diperlihatkan pada Gambar 3 (a). Larutan dalam botol dengan label angka 1 sampai dengan 20 adalah permeat yang dicuplik pada setiap selang waktu 10 menit. Adanya penurunan nilai konsentrasi MB pada permeat sejalan dengan adanya molekul MB yang terserap oleh membran ES seperti terlihat pada Gambar 3(b). 


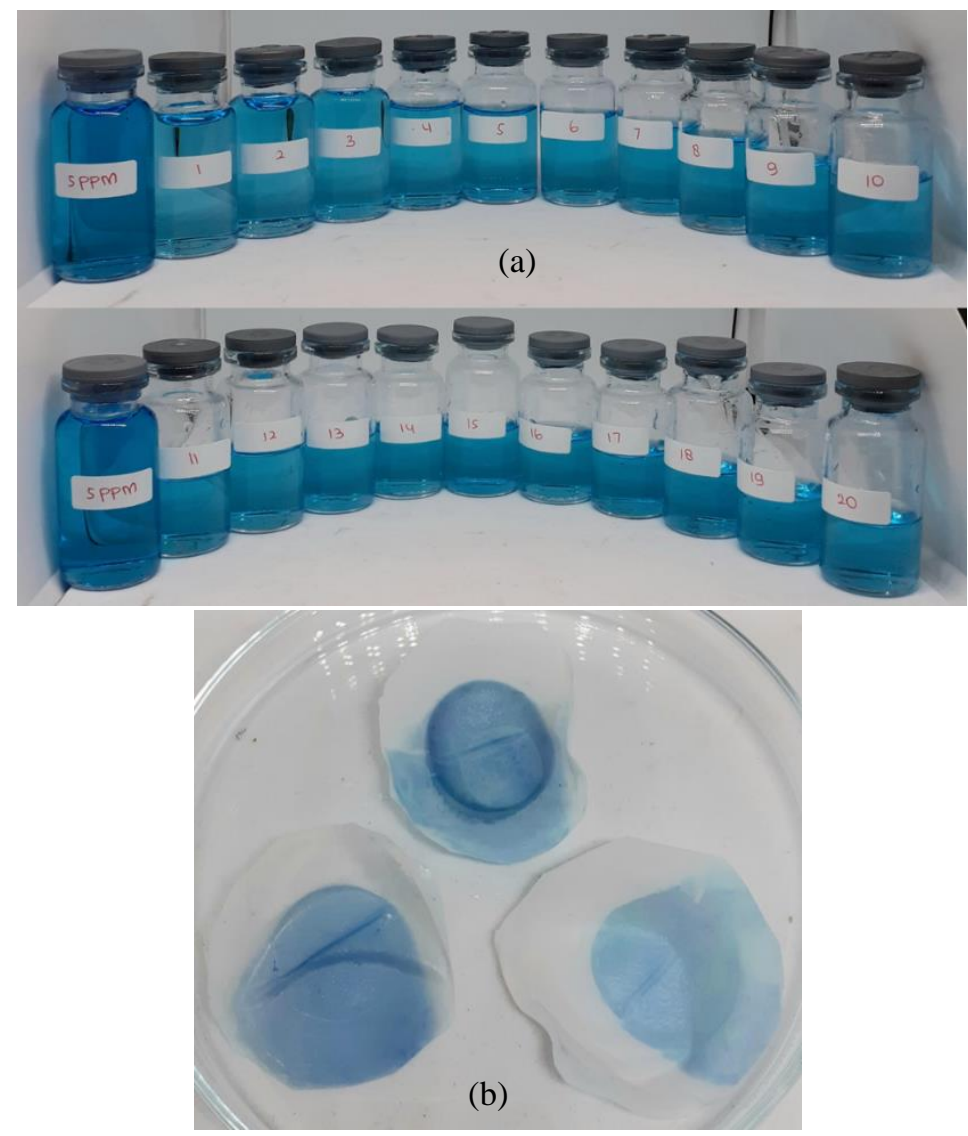

Gambar 3. Larutan MB hasil filtrasi pada setiap selang waktu tertentu (a) dan tampilan permukaan membran ES setelah digunakan pada uji filtrasi (b)

Pada Gambar 4 diperlihatkan spektrum UV Vis dari permeat hasil filtrasi yang penampakan visualnya diperlihatkan pada Gambar 3(a) yang diukur pada rentang panjang gelombang sebesar $500 \mathrm{~nm}$ sampai dengan $750 \mathrm{~nm}$. Pada gambar tersebut tampak bahwa absorbansi permeat lebih kecil dibanding dengan konsentrasi larutan MB sebelum difiltrasi. Hal tersebut mengindikasikan telah terjadi pengurangan konsentrasi larutan MB pada proses filtrasi menggunakan membran ES.

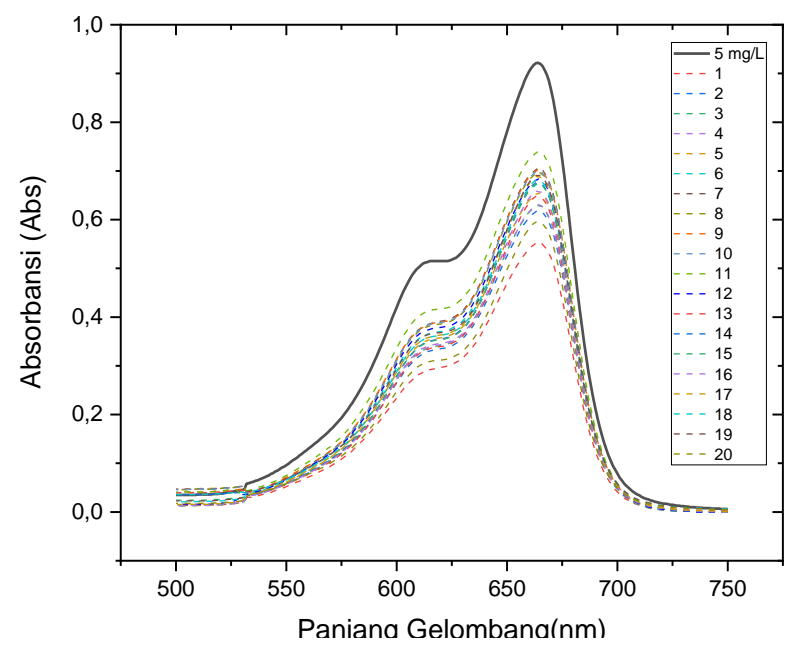

Gambar 4. Spektrum absorbansi larutan MB hasil filtrasi 
Hasil filtrasi menggunakan membran ES menunjukkan adanya penurunan konsentrasi MB. Hasil ini sangat menarik mengingat ukuran molekul MB sangat kecil yang mana dimensinya sekitar $1,4 \mathrm{~nm}$ x $0,6 \mathrm{~nm}$ [10] dibandingkan dengan porositas dari membran ES yang dalam orde mikron. Berkurangnya konsentrasi MB mengindikasikan adanya adsorpsi MB oleh membran ES. Tanpa adsorpsi, molekul $\mathrm{MB}$ akan lolos semua sehingga tidak akan terjadi pengurangan konsentrasi MB. Hasil eksperimen ini telah menunjukkan bahwa membran ES dapat digunakan sebagai filter dalam proses filtrasi membran walaupun hasil filtrasi baru mencapai penurunan sebesar $40 \%$, belum sebaik performa membran GO yang dapat menurunkan konsentrasi MB hingga $90 \%$ jika digunakan sebagai filter [11].

(a)

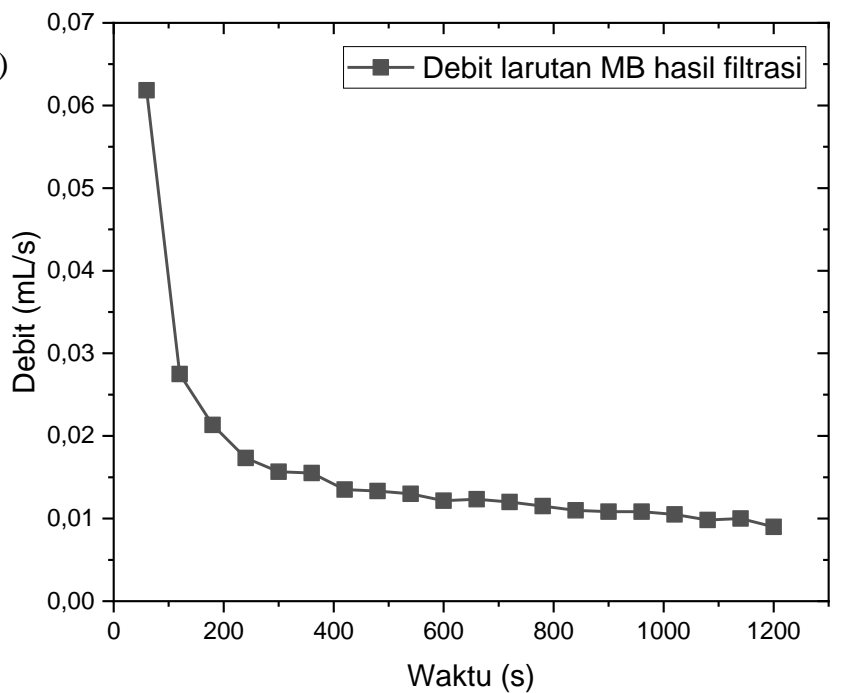

(b)

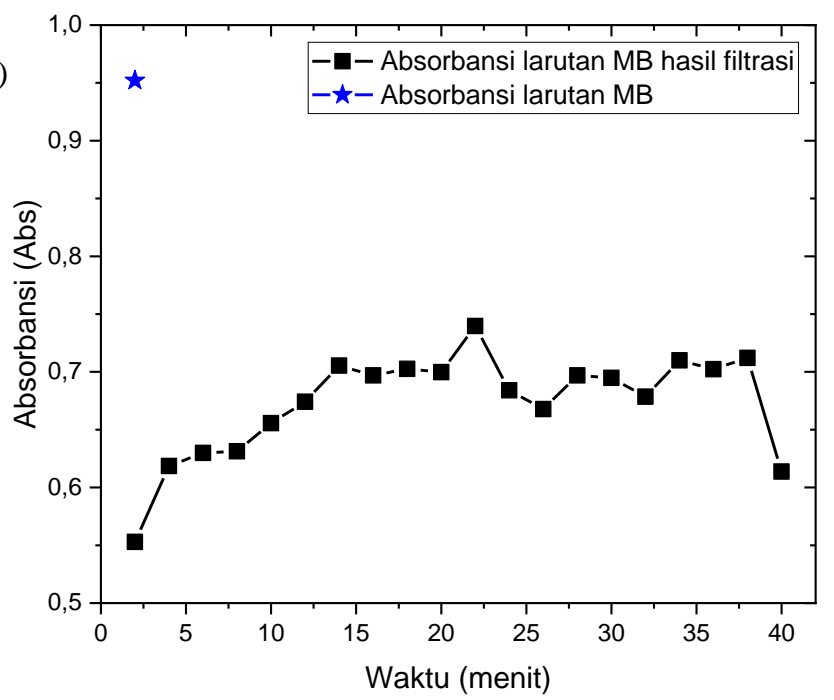

Gambar 5. Debit permeate melalui membran (a) dan absorbansi permeate hasil filtrasi menggunakan tiga lembar membran ES (b)

Karakteristik hasil filtrasi MB dengan menggunakan membran ES diperlihatkan pada Gambar 5 berupa data aliran dan data absorbansi permeat. Pada Gambar 5(a) diperlihatkan data perubahan volume permeat terhadap perubahan waktu (debit) yang terjadi pada proses filtrasi sebagai fungsi waktu. Grafik tersebut mengkonfirmasi bahwa tiga lembar membran ES yang digunakan sebagai filter 
pada uji filtrasi dapat menghasilkan aliran sehingga larutan uji dapat melewati membran ES. Semakin lama waktu filtrasi, debit yang mengalir terlihat makin kecil. Dari Gambar 5.a, debit permeate pada filtrasi akhir dapat diestimasi sebesar 36 $\mathrm{ml} / \mathrm{jam}$. Hal ini mungkin diakibatkan oleh penyumbatan pori-pori membran ES oleh molekul MB yang teradsorpsi oleh permukaan membran. Nilai debit aliran saat filtrasi dapat digunakan untuk menghitung permeabilitas membran dengan menggunakan persamaan (1).

$$
\mathrm{\kappa}=Q\left(\frac{\eta L}{A}\right)\left(\frac{1}{P}\right)
$$

Pada persamaan tersebut $\mathrm{K}$ adalah permeabilitas membran (darcy), $\mathrm{Q}$ adalah laju aliran fluida $\left(\mathrm{cm}^{3} / \mathrm{s}\right), \eta$ adalah viskositas larutan uji (cP), A adalah luas permukaan membran $\left(\mathrm{cm}^{2}\right)$, L adalah ketebalan membran $(\mathrm{cm}), \mathrm{P}$ adalah tekanan (atm).

Dengan menggunakan nilai debit aliran saat filtrasi waktu pertama dan viskositas larutan uji MB didekati dengan nilai viskositas aquades pada suhu $25^{\circ} \mathrm{C}$ yaitu sebesar 0,899 pa.s didapatkan nilai permeabilitas 3 lembar membran ES sebesar $3,64 \times 10^{-5}$ darcy. Nilai permeabilitas ini menggambar kecepatan aliran fluida yang dapat menembus permukaan membran.

Pada Gambar 5(b) diperlihatkan plot antara absorbansi permeat hasil filtrasi pada panjang gelombang $664 \mathrm{~nm}$ terhadap perubahan waktu saat pencuplikan sampel. Pada gambar tersebut tampak bahwa nilai absorbansi permeat tersebut langsung turun sekitar $40 \%$ pada saat pencuplikan sampel pertama dibandingkan dengan absorbansi larutan MB $5 \mathrm{mg} / \mathrm{L}$. Akan tetapi ketika waktu pencuplikan diperpanjang, nilai absorbansi permeat naik kembali dibandingkan dengan hasil filtrasi pertama. Hal ini mungkin diakibatkan terjadi proses pencucian kembali sehingga molekul MB yang semula telah terserap oleh membran ES kembali masuk ke dalam permeat saat proses filtrasi lanjutan.

Data perubahan konsentrasi larutan uji akibat proses filtrasi dipergunakan untuk menentukan koefisien rejeksi membran (R) dengan menggunakan persamaan (2). Parameter $\mathrm{C}_{0}$ menyatakan konsentrasi larutan $\mathrm{MB}$ awal $(\mathrm{mg} / \mathrm{L})$ dan $\mathrm{C}_{\mathrm{n}}$ menyatakan konsentrasi larutan MB akhir (mg/L).

$$
R=\left(\frac{C_{0}-C_{n}}{C_{0}}\right) * 100 \%
$$

Dengan menggunakan kurva kalibrasi, nilai konsentrasi permeat hasil filtrasi dapat ditentukan dari data absorbansi. Perhitungan koefisien rejeksi membran ES terhadap larutan MB sebagai fungsi waktu fitrasi menggunakan persamaan (2) diperlihatkan pada Tabel 1. Nilai koefisien rejeksi rata-rata untuk filtrasi larutan MB menggunakan tiga lembar membran ES adalah sebesar 30,6\%. 
Tabel 1. Koefisien rejeksi membran ES yang dihitung dari perubahan konsentrasi larutan MB hasil filtrasi setiap selang waktu tertentu

\begin{tabular}{|c|c|c|c|c|c|c|c|}
\hline No. & $\begin{array}{c}\text { Waktu } \\
\text { (s) }\end{array}$ & $\begin{array}{l}\text { Absorbansi } \\
\text { MB akhir } \\
\text { (Abs) }\end{array}$ & $\begin{array}{c}\text { Konsentrasi } \\
\text { MB awal } \\
|\mathrm{Co}|(\mathrm{mg} / \mathrm{L})\end{array}$ & $\begin{array}{c}\text { Konsentrasi } \\
\text { MB akhir } \\
|\mathrm{Cn}|(\mathbf{m g} / \mathrm{L})\end{array}$ & $\begin{array}{c}\text { Konsentrasi } \\
\text { MB } \\
\text { teradsorp } \\
\text { ESM }(\mathrm{mg} / \mathrm{L})\end{array}$ & $\begin{array}{c}\text { Koefisien } \\
\text { rejeksi } \\
|\mathbf{R n}|(\%)\end{array}$ & $\begin{array}{c}\text { Koefisien } \\
\text { rejeksi } \\
\text { rata-rata } \\
|\operatorname{Rn}|(\%)\end{array}$ \\
\hline 1 & 60 & 0,5491 & \multirow{20}{*}{4,9778} & 2,8566 & 2,1212 & 42,6131 & \multirow{20}{*}{30,5969} \\
\hline 2 & 120 & 0,6108 & & 3,2051 & 1,7727 & 35,6124 & \\
\hline 3 & 180 & 0,6216 & & 3,2657 & 1,7121 & 34,3949 & \\
\hline 4 & 240 & 0,6229 & & 3,2732 & 1,7045 & 34,2427 & \\
\hline 5 & 300 & 0,6458 & & 3,4020 & 1,5757 & 31,6554 & \\
\hline 6 & 360 & 0,6632 & & 3,5005 & 1,4772 & 29,6770 & \\
\hline 7 & 420 & 0,6927 & & 3,6672 & 1,3106 & 26,3288 & \\
\hline 8 & 480 & 0,6847 & & 3,6217 & 1,3560 & 27,2419 & \\
\hline 9 & 540 & 0,6901 & & 3,6520 & 1,3257 & 26,6332 & \\
\hline 10 & 600 & 0,6874 & & 3,6369 & 1,3409 & 26,9376 & \\
\hline 11 & 660 & 0,7250 & & 3,8490 & 1,1288 & 22,6763 & \\
\hline 12 & 720 & 0,6726 & & 3,5535 & 1,4242 & 28,6116 & \\
\hline 13 & 780 & 0,6390 & & 3,3639 & 1,6138 & 32,4212 & \\
\hline 14 & 840 & 0,6660 & & 3,5163 & 1,4615 & 29,3604 & \\
\hline 15 & 900 & 0,6640 & & 3,5050 & 1,4728 & 29,5871 & \\
\hline 16 & 960 & 0,6490 & & 3,4203 & 1,5574 & 31,2876 & \\
\hline 17 & 1020 & 0,6780 & & 3,5840 & 1,3938 & 28,0001 & \\
\hline 18 & 1080 & 0,6710 & & 3,5445 & 1,4333 & 28,7936 & \\
\hline 19 & 1140 & 0,6800 & & 3,5953 & 1,3825 & 27,7734 & \\
\hline 20 & 1200 & 0,5890 & & 3,0818 & 1,8960 & 38,0892 & \\
\hline
\end{tabular}

\section{Kesimpulan}

Membran ES dapat dihasilkan dari kulit telur melalui perendaman dalam asam asetat konsentrasi 15\% selama 30 menit. Hasil uji filtrasi menggunakan 3 lembar membran ES untuk menyaring larutan MB dengan konsentrasi $5 \mathrm{mg} / \mathrm{L}$ pada tekanan 3,4 atm berhasil menurunkan konsentrasi MB. Membran ES sebanyak tiga lembar dapat digunakan untuk menyaring molekul MB dengan nilai permeabilitas $3,64 \times 10^{-5}$ darcy dan nilai koefisien rejeksi rata-rata $30,6 \%$ serta debit permeat sebesar $36 \mathrm{~mL} / \mathrm{jam}$.

\section{Ucapan Terima Kasih}

Penelitian ini didanai oleh Proyek Penelitian Dasar Unggulan Perguruan Tinggi (PDUPT) nomor kontrak 1207/UN6.3.1/PT.00/2021 tanggal 9 Maret 2021. 


\section{Daftar Pustaka}

1. M.A. Rauf, Meetani, A. Khaleel, and A. Ahmed, Photocatalytic degradation of Metilen biru using a mixed catalyst and product analysis by LC/MS. Chemical Engineering Journal 157 (2010), 373.

2. Y.H. Liu, X.H. Cao, R. Hua, Y.Q. Wang, Y.T. Liu, C. Pang and Y. Wang, Selective adsorption of uranyl ion on ion-imprinted chitosan/PVA cross-linked hydrogel. Hydrometallurgy, 104 (2010). 150.

3. E. O. Ezugbe, S. Rathilal, Membrane Technologies in Wastewater Treatment: A Review, Membranes 10 (2020), 89

4. A. O. Adegbenjo, L. Liu and M. O. Ngad, Non-Destructive Assessment of Chicken Egg Fertility, Sensors, 20 (2020), 5546.

5. S. Park, K. S.Choi, D. Lee, D. Kim, K. T. Lim, K-H Lee, H.Seonwoo, J. Kim, Eggshell membrane: Review and impact on engineering, Biosystems Engineering 151 (2016), 446

6. A. Mittal, R.K. Soni, J. Mittal, Applications of egg shell and egg shell membrane as adsorbents: A review, Journal of Molecular Liquids 223 (2016), 376

7. W-T. Tsai, K-J. Hsien, H-C. Hsu, C-M. Lin, K-Y Lin, C-H. Chiu, Utilization of Ground Eggshell Waste as an Adsorbent for the Removal of Dyes from Aqueous Solutio, Bioresource Technology 99 (2008) 1623.

8. M. Arami, N. Y. Limaee, N. M. Mahmoodi, Evaluation of the adsorption kinetics and equilibrium for the potential removal of acid dyes using a biosorbent, Chemical Engineering Journal 139 (2008), 2

9. X. He, D.Yang, X. Zhang, M.Liu, Z. Kang, and C. Lin, Waste Eggshell Membrane-Templated CuO-ZnO Nanocomposites with Enhanced Adsorption, Catalysis and Antibacterial Properties for Water Puri Fi Cation, Chemical Engineering Journal 369 (2019), 621

10. J. De Souza Macedo, N.B.da Costa Júnior, L.E. Almeida, E.F. da Silva Vieira, A.R.Cestari, I.de Fátima Gimenez, N.L.Villarreal Carreno, L.S. Barreto, Kinetic and calorimetric study of the adsorption of dyes on mesoporous activated carbon prepared from coconut coir dust. J. Colloid Interface Sci. 298 (2006), 515

11. H. Kalita, H. Tyagi and M. Aslam, Surface-tailored graphene oxide paper: an efficient filter for dye pollutants, Environ. Sci.: Water Res. Technol., 6 (2020), 963 